\title{
Pisces, Cyprinodontiformes, Rivulidae, Austrolebias periodicus (Costa, 1999): Distribution extension in state of Rio Grande do Sul, southern Brazil
}

\author{
Matheus Vieira Volcan*, Luis Esteban Krause Lanés and Ândrio Cardozo Gonçalves \\ Instituto Pró-Pampa (IPPampa), Laboratório de Ictiologia. Rua Gomes Carneiro, 1043, Centro. CEP 96010-610. Pelotas, RS, Brazil. \\ * Correspondence author email: matheusvolcan@hotmail.com
}

\begin{abstract}
The present note extends the distribution of annual killifish Austrolebias periodicus, a endangered species, endemic of the Pampas region, in Ibicuí River basin, state of Rio Grande do Sul, southern Brazil. This information is needed to develop conservation strategies for this species and its habitat, which are at high risk due to the expansion of rice production and exotic forests in southern Brazil.
\end{abstract}

The Neotropical genus Austrolebias Costa (Aplocheiloidei, Rivulidae) comprises a diversified clade of fishes, inhabiting seasonal pools formed during the rainy season in southern Brazil, Paraguay, Uruguay, and northern and northeastern Argentina. All species of Austrolebias are annual fishes, living in temporary pools and swamps. In the Pampas region, including Uruguay, Buenos Aires and Entre Rios provinces of Argentina and southern Brazil, pools are usually formed during the winter months (Costa 1998; 2002a; 2006).

Species of this genus are characterized by the absence of scales in the corner of the mouth and the anterior portion of the pre-ocular region, deep urohyal, presence of a grayish to blackish supraorbital spot, rounded dorsal fin and elongated anal and urogenital papilla (Costa 1998; 2006). The genus has recently been redefined phylogenetically by Costa (2006).

The annual fish A. periodicus (Costa 1999) (Figure 1) is registered for the drainages of rivers Ibicuí and Quaraí, Uruguay River basin, southern Brazil and northwestern Uruguay (Costa 1999; 2006) (Figure 2A). This taxon belongs to the "species group" Austrolebias alexandri Costa (2002b), and differs from other species of the group by the posterior margin of each pectoral fin in the male reaching vertical between base of second and fifth anal-fin rays, dorsal-fin origin either on vertical through anal-fin origin or subsequent to it, and larger males with vertical rows of light blue dots on entire (Costa 2006). Perujo et al. (2005) described $A$. luzardoi from the Quaraí River drainage, adjacent to the Ibicuí River, where the type locality of $A$. periodicus is located. Costa (2006), examining topotypes of $A$. luzardoi, reveals that it is indistinguishable from $A$. periodicus.

The species is recorded in small ponds, where it feeds mainly on aquatic invertebrates and has low ecological plasticity (Fontana et al. 2003). It is considered threatened in category "Vulnerable", which is due to its restricted area of occurrence and advanced degree of loss and fragmentation of its habitat, mainly due to rice cultivation in the area of occurrence (Fontana et al. 2003; Rosa and Lima 2008). Austrolebias periodicus (Figure 1) distribution in Brazil was only known to four populations in Dom Pedrito and Rosário do Sul municipalities, Santa Maria and Ibicuí da Armada rivers basins respectively (Fontana et al. 2003; Costa 1999; 2002b; 2006). In this study its occurrence is extended to four new areas and two new municipalities, all located in the Ibicuí River basin (Figure 2B).

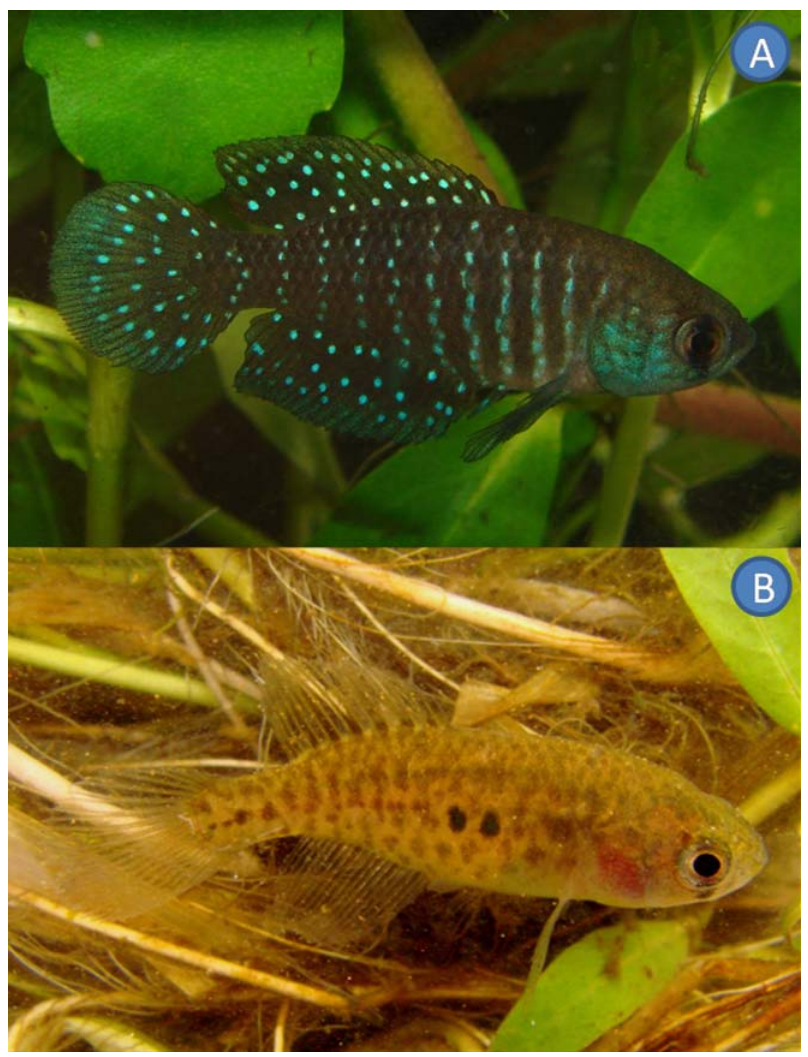

Figure 1. Male (A) and female (B) of Austrolebias periodicus, captured in Lajeadinho stream floodplains, Alegrete, Brazil. Photo by Matheus V. Volcan. 

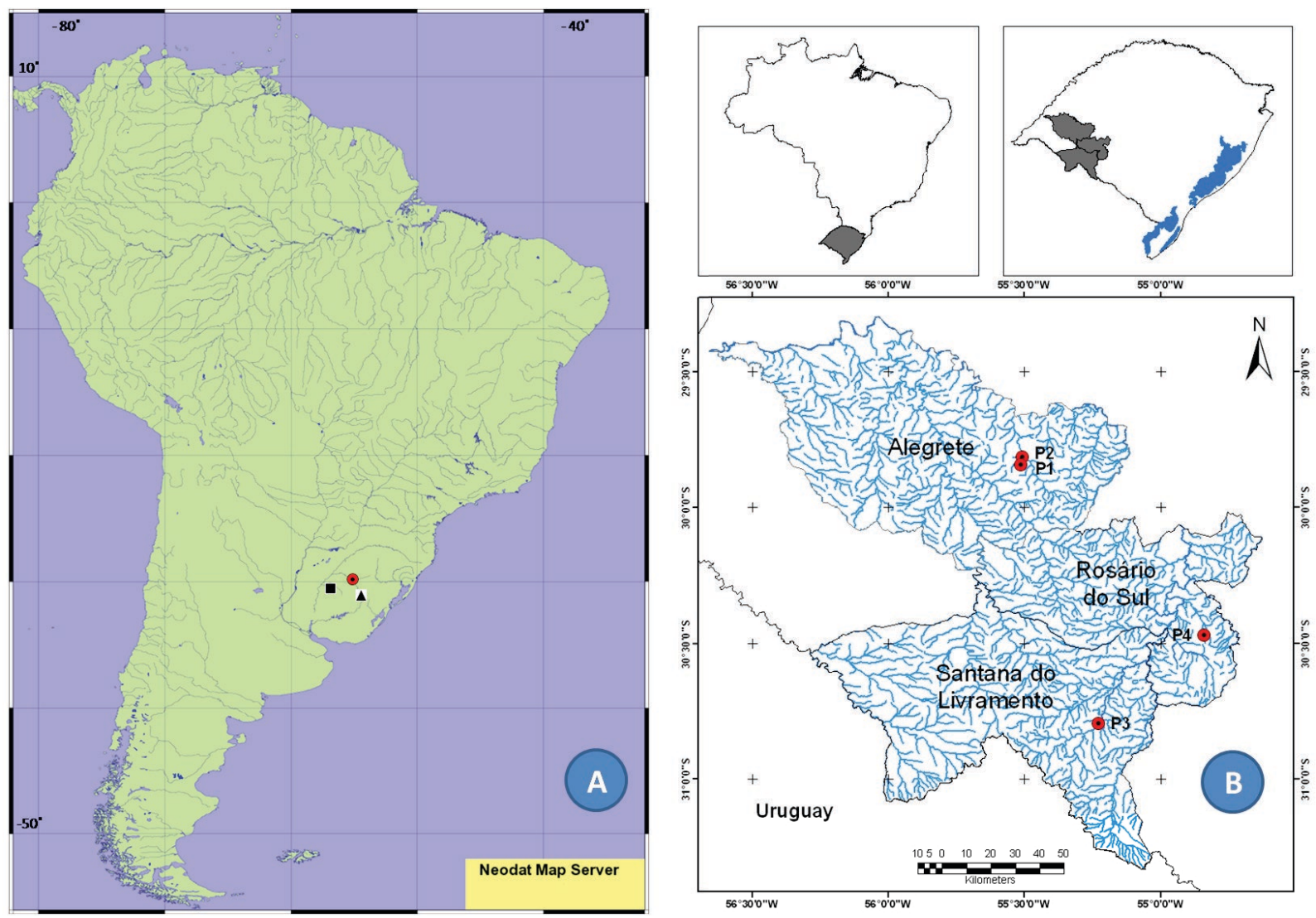

FiguRE 2. (A) Previous known distribution of Austrolebias periodicus including Ibicuí River basin in Brazil ( $\mathbf{\Delta}$ ), Quaraí River basin in Uruguay( $\mathbf{\square})$, and the current record (-). Modified from NEODAT (2010). (B) Map detailing the new occurrences of Austrolebias periodicus in state of Rio Grande do Sul, southern Brazil. Author: H. P. B. Neto. P1 and P2. Floodplain of the Lajeadinho stream. P3. Pond marginal to Tarumã stream. P4. Floodplain of the Ibicuí da Faxina stream. Source: Modified from Embrapa Monitoramento por Satélite (2005) and FEPAM (2005).

Capture was done with D-shaped hand nets of $2 \mathrm{~mm}$ mesh and $60 \times 50 \mathrm{~cm}$. The specimens were fixed in $10 \%$ formalin and stored in $70 \%$ alcohol. The material was collected with IBAMA/ICMBio authorization, process number 18334-1, and it is deposited in the ichthyologic collection of the Federal University of Rio de Janeiro (UFRJ).

During collection campaigns carried between 2007 and 2009 in western Rio Grande do Sul, 15 specimens of four populations of $A$. periodicus (Figure 1) were recorded in reduced and extremely shallow ponds, with a high density of aquatic macrophytes (Figure 3), at altitudes ranging between 85 and $130 \mathrm{~m}$ above sea level.

Two of these populations were located in the municipality of Alegrete, in temporary wetlands localized in Lajeadinho stream floodplains $\left(29^{\circ} 50^{\prime} 33^{\prime \prime}\right.$ S, 55 $30^{\prime} 41^{\prime \prime}$ $\mathrm{W}$ and $29^{\circ} 49^{\prime} 45^{\prime \prime} \mathrm{S}, 55^{\circ} 30^{\prime} 25^{\prime \prime} \mathrm{W}$ ). One population was captured in the municipality of Santana do Livramento, floodplain of Ibicuí da Faxina stream $\left(30^{\circ} 47^{\prime} 47^{\prime \prime}\right.$ S, $55^{\circ} 13^{\prime} 38^{\prime \prime}$ W) and another population in the floodplain of Tarumã stream, tributary of the Ibicuí da Armada, municipality of Rosário do Sul $\left(30^{\circ} 28^{\prime} 09^{\prime \prime}\right.$ S, 54 $50^{\circ} 17^{\prime \prime}$ W) (Figures 2B-3).

In the four areas where the species was captured, the rice culture and exotic forestry (especially eucalyptus) are the human activities that deserve more attention with regard to the conservation of $A$. periodicus, since these planctations were recorded close to their biotopes. The endemism of the species, the advanced state of degradation of their biotopes and the impacts that its populations are subject, demonstrate the urgent need for implementation of conservation strategies. According to Rosa and Lima (2008), annual fishes as A. periodicus generally occupy temporary ponds of reduced extension and thus the protection of relatively small areas can ensure the preservation of the species. However, fragmentation and habitat loss prevent connection of these wetlands inhabited by Rivulidae and dispersal of species in floodplains. Thus, besides the need to protect their restricted habitats, the establishment and creation of large protected areas,

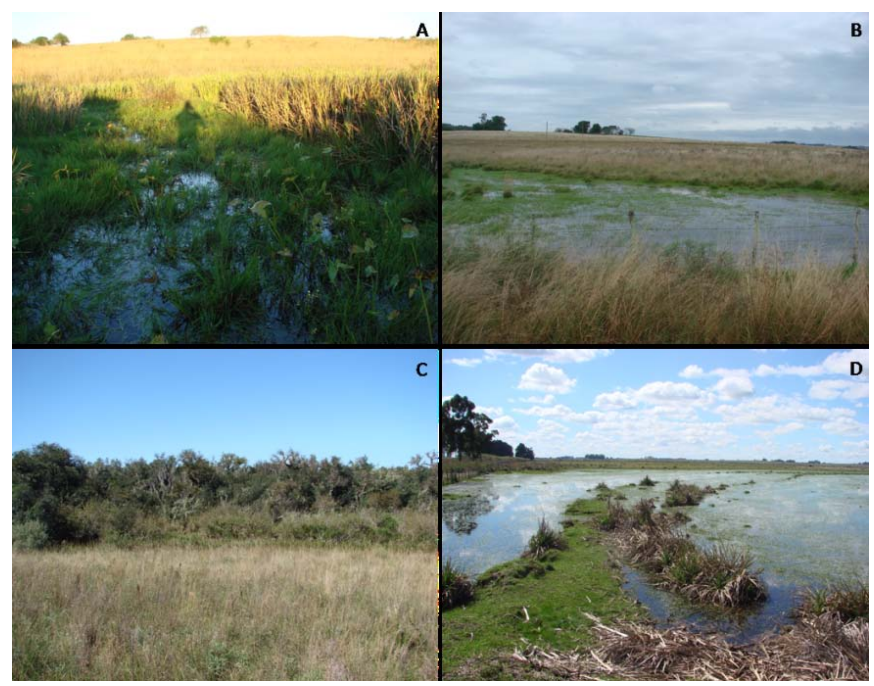

FIGURE 3. Image of the habitats of occurrence of Austrolebias periodicus in the state of Rio Grande do Sul, Brazil. (A) and (B) Ponds located near the floodplain of the Lajeadinho stream, Alegrete. (C) Pond marginal to Tarumã stream, tributary of the Ibicuí da Armada River in the municipality of Rosario do Sul. (D) Wetland near the floodplain of the Ibicuí da Faxina stream in Santana do Livramento. Photos by Luis E.K. Lanés. 
mainly along river corridors and associated wetlands of the Ibicuí River basin should be performed also in order to enable connectivity and dispersal populations of $A$. periodicus, assisting in their conservation.

ACKNOWLEDGMENTS: We thank Bruno Klotzel for assistance in collecting, Hélio Neto by editing the figures and Afrânio Fonseca for their assistance in translating the manuscript. Wilson J.E.M. Costa, confirmed the identification of specimens. This paper was improved by the comments of one anonymous reviewer.

\section{Literature Cited}

Costa, W.J.E.M. 1998. Phylogeny and classification of Rivulidae revisited: evolution and miniaturization of rivulid fishes (Cyprinodontiformes: Aplocheiloidei). Journal of Comparative Biology 3(1): 32-92.

Costa, W.J.E.M. 1999 Cynolebias periodicus, a new annual fish from the rio Ibicuí drainage, southern Brazil (Cyprinodontiformes: Rivulidae). Ichthyological Exploration of Freshwaters 10: 297-302.

Costa, W.J.E.M. 2002a. Monophyly and phylogenetic relationships of the neotropical annual fish genera Austrolebias and Megalebias (Cyprinodontiformes: Rivulidae). Copeia 4: 916-927.

Costa, W.J.E.M. 2002b. The Austrolebias alexandri species group: a taxonomical revision of an annual fish clade (Cyprinodontiformes: Rivulidae) in southern Brazil. Comunicações do Museu de Ciências e Tecnologia da PUCRS, série Zoologia 15: 87-111.

Costa, W.J.E.M. 2006. The South American annual killifish genus
Austrolebias (Teleostei: Cyprinodontiformes: Rivulidae): phylogenetic relationships, descriptive morphology and taxonomic revision. Zootaxa 1213: 1-162.

FEPAM. 2005. Fundação Estadual de Proteção Ambiental Henrique Luiz Roessler, RS. Biblioteca Digital. Arquivos digitais para uso em SIG. Base cartográfica Digital do RS 1:250.000. Accessible htttp://www.fepam. rs.gov.br/biblioteca/geo/bases_geo.asp. Captured on 10 November 2009.

Fontana, C.S., G.A. Bencke and R.E. Reis. 2003. Livro vermelho da fauna ameaçada de extinção no Rio Grande do Sul. Porto Alegre: Edipucrs. $632 \mathrm{p}$.

NEODAT 2010. Inter-Institutional Database of Fish Biodiversity in the Neotropics (NEODAT). Electronic database accessible at http://www. neodat.org. Captured on 16 March 2010.

Perujo, E., P.A. Calviño, H. Salvia and F. Prieto. 2005. Austrolebias luzardoi (Cyprinodontiformes: Rivulidae), una especie nueva de pez anual de la cuenca del río Cuareim, República Oriental del Uruguay. Revista del Museo de La Plata 17: 1-12.

Rosa, R.S. and F.C.T. Lima. 2008. Peixes; p. 8-285. In Machado, A.B.M., G.M. Drummond and A.P. Paglia (ed.). Livro vermelho da fauna brasileira ameaçada de extinção. Brasília: Ministério do Meio Ambiente.

RECEIVED: January 2010

REVISED: March 2010

ACCEPTED: April 2010

Published ONLINE: May 2010

EDITORIAL RESPONSIBILITY: Marcelo Loureiro 